\title{
Tanzimat Dönemi’nde Rüşvet ve Yolsuzluk: Diyarbakır Meclis Üyesi Hacı Şeyh A ğa'nın Davası
}

\section{Bribery and Corruption in the Tanzimat Era: The Case of Diyarbakır Council Member Hacı Şeyh Ăga Özlem KARSANDIK YAZICI*}

\begin{abstract}
$\ddot{O} \mathbf{z}$
Osmanlı'nın kuruluş yıllarından itibaren var olan rüşvet ve yolsuzluğa dair Tanzimatla birlikte birçok düzenleme yapılmıştır. Ancak bu dönemde de rüşvet ve yolsuzlukla ilgili suçlamalar ve bu suçlamalara istinaden yürütülen davalara her kademedeki yönetici kesiminde rastlanmaktadır. Diyarbakır Meclis Azası Hacı Şeyh Ağa'nın usulsüz uygulamaları nedeniyle açılan dava da bunlardan birini oluşturmaktadır. Çalışmamızda Hacı Şeyh Ağa'nın davası örneğinden hareketle Tanzimat Döneminde rüşvet ve yolsuzluğa dair işleyiş, yolsuzluğa yol açan uygulamalar, bu tür suçlara verilen cezalar değerlendirilmiştir.
\end{abstract}

Anahtar Kelimeler: Tanzimat, Rüşvet, Hacı Şeyh Ağa, Dava.

\section{Abstract}

Many regulations were made with the Tanzimat Era on bribery and corruption that had existed since the foundation years of the Ottoman Empire. However, in this period, accusations of bribery and corruption and lawsuits based on these accusations were encountered in all the levels of administration. The lawsuit filed due to the irregular practices of Hacı Sheikh Ağa, a Member of Diyarbakır Council was one of them. In the current study, based on the example of Hac1 Sheikh Ağa's case, how bribery and corruption were handled in the Tanzimat period, the practices that led to corruption and the penalties for such crimes were evaluated.

Keywords: Tanzimat, Bribery, Hacı Sheikh Ağa, Lawsuit.

\section{Giriş}

Çeşitli şekillerde tanımlanan yolsuzluk, yasal olmayan ve etik dişı birçok konuyu içermektedir. Tanımlarının genelinde kamuyla ilişkilendirilmektedir (Al, 2005, s. 239; Özsemerci, 2002, s. 5). Maddi çıkar karş1lığ1 yolsuzluğun türü olarak ele alınan rüşvet, örgütlenen tüm topluluklarda görülmüştür (Kahraman, 2010, s. 5; Özsemerci, 2002, s. 16). En genel anlamda menfaatle usul ve kural dışı bir işin yetkili birine yaptırılması olarak tanımlanan rüşvet (Mumcu, 1985, s. 20-21; Daşcioğlu, 2005, s. 119), Osmanlı Devleti'nin kuruluşundan itibaren var olan sorundur (Mumcu, 1985, s. 86-162). II. Mahmut döneminde memuriyete girişte sınav sisteminin uygulamaya konulması (Akyıldı, 1993, s. 54), memurlara yeterli maaş tahsis edilmesi ve ceza kanunnamesi ${ }^{1}$ hazırlanması rüşvet ve yolsuzlukları engellemek adına atılmış önemli adımlardı (Mumcu, 1985, s. 275-78; Keleş, 2005, s. 260). Bu kanunnameye hazırlanan ekle rüşvet olarak tanımlanan hediyelerin niteliği belirlenmiştir (Bkz. Veldet, 1999, s. 171-172). Ancak tüm bu uygulamalar toplumda yaygın olarak var olan rüşvet suçunu azaltmaya yetmemiştir. 1839'da ilan edilen Tanzimat Fermanı'nda da rüşvete dair önlem alınması gerektiği vurgulanmıştı (Mumcu, 1985, s. 278; Keleş, 2005, s. 263). Nitekim Tanzimat Dönemi'nde yapılan kanunlarda rüşvete ve yolsuzluğa dair maddeler yer almıştır. Tanzimat Fermanın gereğini yerine getirmek ve kişisel keyfilikleri engellemek amacıyla ilk Ceza Kanunnamesi 1840'de çıkarılmıştır (Cin, 1992, s. 19; Taner, 1999, s. 226;Üçok, 2007, s. 343). Bu kanunname ile rüşvet alma suçu memurlar ekseninden çıkartılarak tüm hizmetliler olarak genişletilmiş, ayrıca rüşvet suçuna verilecek cezada kanunnamede belirtilmiştir. Buna göre rüşvet veren ve alan kişinin memuriyetten ihraç

\footnotetext{
* Dr. Öğr. Üyesi, Muğla Sitkı Koçman Üniversitesi, Edebiyat Fakültesi, Tarih Bölümü, ozlemyazici@ mu.edu.tr

${ }^{1} 1838$ 'de oluşturulan “Tarik-i İlmîyye'ye Dâir Cezâ Kanunnamesi”nde memurların rüssvet suçuna dair uygulanacak cezalara yer verilmiştir. Kanunnameye dair ayrıntılı bilgi için bkz. Musa Çadırcı, "Tanzimat'ın İlanı Sıralarında Osmanlı İmparatorluğu'nda Kadılık Kurumu ve 1838 tarihli "Tarik-i İlmîyye'ye Dâir Cezâ Kanunname'si”, DTCF Tarih Araştırmaları Dergisi, Cilt:XIV/25, Ankara 1982, s.139-161.
}

Yazıcı Karsandık, Ö., (2022). Tanzimat Dönemi’nde Rüşvet ve Yolsuzluk: Diyarbakır Meclis Üyesi Hacı Şeyh Ağa'nın Davası, Asia Minor Studies, Cilt 10 Sayı 1, 42-53, Gönderim tarihi: 28-11-2021, Kabul tarihi: 21-012022.

Araştırma Makalesi. 
edilmesi ve (üç yıl) kürek cezası ile cezalandırılması kararlaștırılmış ancak rüșvet veren eğer buna mecbur bırakılmışsa bunu ispat ettiği takdirde suçsuz kabul edileceği de belirtilmiştir (Mumcu, 1985, s. 278-279). Tüm bu alınan önlemlere rağmen vergi toplamadaki usulsüzlükler devam etmiş bu nedenle 1849 'da esas olarak yöneticilerin görevlerini yeniden belirlemek için yapılan düzenlemelerin bazı maddeleri de rüşvet ve yolsuzluklara ayrılmıştır (Çadırc1, 1997, s. 218-219). 1850'de ise 1slahatların yerine getirilebilmesi için devlet adamlarının Meclis-i Vala-yı Ahkam-1 Adliye görüşmeleri öncesinde Kur'an üzerine yemin etme uygulaması başladı (Ahmet Lütfi Efendi, 1984, s. 17). Bu uygulama gereğince taşrada da memurlar halkın huzurunda yemin işlemini gerçekleştirdi (Mumcu, 1985, s. 279-280). Bunların dışında rüşvet olarak tanımlanabilecek hediyelerin ayrıntıları yine 1850'de hazırlanan bir nizamname ile belirlendi.1850'de hediyelerle ilgili yeni bir düzenleme yapıldı (Çelik, 2006, s. 53;55;58). 1851'de "Kanun-1 Cedid" olarak adlandırılan bir kanunname daha hazırlanmıştır (Üçok, 2007, s. 344).1855'de rüşvetin nedenleri ve uygulamaların etkisiz olmasının sebeplerinin değerlendirildiği yeni bir nizamname düzenlendi (bkz. Akgündüz, 1987, s. 159-162; Üçok, 2007, s. 344). 1858'de ise önceki nizamnamenin maddelerini içeren ancak suçluların cezalarına yönelik değişikliklerin yapıldığı Ceza Kanunnamesi yayınlanmıştır (Keleş, 2005, s. 271, 274-279).

Tanzimat döneminde rüşvet ve yolsuzluğa dair verilen mücadele de sadece verilecek cezaları belirlemekle yetinilmemişti. Bu cezaları belirleyecek ve rüşvetle mücadele edecek kurumların da varlığına ihtiyaç duyulmuştur. Nitekim büyük meclislerin idari görevlerinin yanı sıra adli görevleri de bulunmaktaydı. 1864 düzenlemesine kadar önce büyük meclisler, 1854 'den sonra oluşturulan meclis-i tahkikler adli işlerden sorumlu olmuşlardır (Bingöl, 2004, s. 76-86). Meclis-i Tahkikler, uygulamada çoğunlukla büyük meclis içerisinde aynı ekiple toplanan bir kurum olmuştur. Taşrada davalar nizamiye mahkemeleri oluşturulana kadar "Meclis-i Tahkik", "Büyük Meclis", "Meclis-i Vala” sistemi içinde çözülmüştür. Dava konusunun niteliği hangi mecliste karar verileceğini belirlemekteydi. Buna göre k1sas ve diyet davalarında karar merci büyük meclis iken diğerlerinde tahkik meclisiydi. Verilen cezalar Meclis-i Vala'da temyiz edilmekteydi (Ekinci, 2004, s. 139-145; Akgündüz, 1987, s. 170). Bilindiği üzere Tanzimat'ın uygulanmaya başlaması bölgelere göre farklılık göstermektedir. Nitekim Diyarbakır'da Tanzimat 1845'te uygulanmaya başlamış (Yılmazçelik, 2019, s. 3638 ;4) ve bu uygulamanın bir gereği olan "Büyük Meclis" 1851'de oluşturulmuştur (Keleş, 2019, s. 362).

Çalışmamızda Diyarbakır Büyük Meclis azası Hacı Şeyh Ağa'ya yapılan suçlamalar, dava süreci, sonucu ve af talepleri ekseninde 19. yüzyılda Osmanlı'da rüşvet ve yolsuzluğun nedenleri, bu tip suçlarda dava sürecinin nasıl işlediği ve verilen cezalar değerlendirilmiştir. Diyarbakır Büyük Meclis azası Hacı Şeyh Ağa'nın hayatı ile ilgili net bilgiler mevcut değilse de çeşitli belgelerde kapıcıbaşı unvanına sahip olduğuna vurgu yapılmıştır. Bu bilgi onun taşra idaresinde ve devlet adına çeşitli görevlerde bulunduğuna işaret etmektedir. Ayrıca yine dava ile ilgili belgelerde satır aralarında yer alan ifadelerden sekiz çocuğu olduğu anlaşılmaktadır (BOA, MVL 512/23095-1).

\section{Hacı Şeyh Ağa'ya Atfedilen Suçlar}

Diyarbakır Büyük Meclis azası Hacı Şeyh Ağa'nın rüşvet olarak özetlenmiş dava dosyası incelediğinde, adam kayırma, yolsuzluk yapmak ve haksız menfaat elde etmek gibi suçlamalara maruz kaldığı anlaşılmaktadır (BOA, MVL 484/21943). Bu bağlamda 15 Ocak 1862 tarihli belgede Hacı Şeyh Ağa'nın istediğini elde etmek için muhalifleri görevlerinden azlettiği ve yerlerine kendi adamlarını tayin ettiği, bu durumun halkın korkuya kapılmasına ve huzursuz olmasına sebep olduğu ifade edilerek meclis azalığından azledilmesi gerektiği belirtilmiştir (BOA, MVL 627/78-2). Nitekim Nisan 1862'de Meclis-i Vala'nın, şikayetleri ciddi bulması üzerine Hacı Şeyh Ağa hakkındaki iddiaların araştırılması için harekete 
geçildiği anlaşılmaktadır (İ.MVL 484/21943; A. MKT. NZD 410/15). Gerek mahkeme tutanakları gerekse çeşitli arşiv belgelerinde yer alan bilgilerle Hacı Şeyh Ağa'ya yöneltilen suçlar şu şekilde özetlenebilir.

Suçlamalardan biri Derik Meclis azası Reşit Kethüda'nın ölümüne sebep olacak gelişmelere ortam hazırlamasıdır. Bu bağlamda olmak üzere Reşit Kethüda ve Seyithan Derik kaza meclisi azası iken uygunsuz tavırlarından dolayı azalıktan azledilip kazadan sürgün edilmiştir. Hacı Şeyh Ağa'nın damadı Laçin Bey ve akrabası Mehmet Ağa, 1276 (1859-60) yılı Derik Kazası aşar iltizamını almıştır. Ancak Hacı Şeyh Ağa Derik Meclis Azalarını Diyarbakır'a getirterek söz konusu aşar hasılatına urban tarafından zarar verildiği gerekçesiyle alamadıklarını ve üzerine 82 kile daha ilave edilerek alınması yönünde senet talep etmiştir. Derik Meclis azaları karşı çıksalar da Ağa baskıyla senedi imzalatmıştır. Yine aşar iltizam bedelinin toplanması gerektiğinden Hacı Şeyh Ağa, büyük meclisin kararına aykırı olmasına rağmen büyük meclis üyelerinin haberi olmaksızın söz konusu Derik Kazası azalarına Reşit Kethüda ve Seyithan'1 tekrar Derik Kazası meclis azası tayin ettirmiştir. Sürgüne gönderilmiş olan Derik meclis azası Reşit Kethüda ve Seyithan'1n tekrar kazaya dönerek görevlerine başladıklarının haber alınması üzerine halk tepki göstermiş ve meclis üyelerinin evlerine saldırmıştır. Bu karışıklık sırasında meclis azası Reşit Kethüda öldürülmüştür. Reşit Kethüda'nın ölümü sonrası yapılan tahkikatta, azledilmeleri ve tekrar meclis azası tayinlerinden büyük meclisin haberinin olup olmadığı araştırılır. Derik Kazası müdürü Hasan Ağa ise bu kişilerin tekrar kaza meclisi azası tayin edilmeleri hususunda gönderilen Derik kaza meclis kararının olduğunu ifade ederek buna dair 30 Temmuz 1860 tarihli tahriratı ortaya çıkarır. Bu belge üzerine Reşit Kethüda ve Seyithan'ın büyük meclisin haberi olmaksızın tekrar Derik Kazası meclis azası tayin edilmeleri hususunda Hacı Şeyh Ağa'nın nasıl bir çıkarı ve rolü olduğu gerçeğini araştırmaya başlanmıştır (BOA, MVL 484/21943).

Soruşturma kapsamında Derik Kazası meclis azaları (Abdulfettah, Sinan, İsmail, Resul, diğer Resul) Kaza Müdürü Hasan, Hacı Şeyh Ağa, Hacı Nuh Ağa, Narızade Hacı Mehmet Ağa, Kethüda Kâtibi Mustafa ve Mukayyid Veli Efendi'nin ifadelerine başvurulmuştur (BOA, MVL 484/21943). Derik Kazası meclis azaları, Reşit ve Seyithan'ın azledilmeleri hakkında alınan kararda ve yine bu şahısların tekrar meclis azası tayin edilmeleri hususundaki onay kararında mühürlerinin olması sebebiyle sorgulanmışlardı. Soruşturma kapsamında 20 Nisan 1862 tarihinde Derik Meclis azası Abdulfettah'ın ifadesi alınır. Bu sorgulamada Abdulfettah'a Reşit ve Seyithan hakkında iki zıt görüşün olduğu evraklarda bulunan mühürlerinin nedeni sorulmuştur. Abdulfettah bu konuda verdiği cevapta, Seyithan ve Reşit'in azledilmeleri ve sürgüne gönderilmeleri hususunda alınan karara dair mahzarın oybirliği ile alındığını ve imzalandığını, hatta bunların kazaya dönmeleri halinde karışıklık çıkacağını ifade ettiklerini beyan etmiştir. Devamında ise tekrar meclis azası tayin edilmelerine dair kararın iradesi dışında alındığını satır aralarındaki ifadesinde söylemiştir (BOA, İ.MVL 484/21943).Reşit ve Seyithan'ın azalığı ile ilgili diğer azaların ifadelerinde de benzer bilgeler yer almaktadır. Özetle hemen hemen hepsi benzer ifadelerle Hacı Şeyh A ğa'nın kendilerini hapse atmakla tehdit ettiğini hatta hapishane önüne kadar götürerek korkuttuğunu ve söz konusu kararı yazdıklarını söylemektedirler. Verdikleri arzuhalin Reşit'in ölümüne neden olduğunu doğrulamakta ancak bunu yapmaya mecbur birakıldıklarını ve korktukları için de Hacı Şeyh Ağa'yı şikayet edemediklerini net olarak dile getirmektedirler (BOA, İ.MVL 484/21943; BOA, İ.MVL 484/21943). Bu soruşturma kapsamında daha önce belirtildiği gibi Derik Kazası müdürü Hasan Ağa'nın ifadesi alınmıştır. Hasan Ağa, valinin emri üzerine tayin ettiğini ifade etmiştir (BOA, İ.MVL 484/21943). Yapılan tahkikat sonrası Hasan Ağa'nın doğru söylediği ortaya çıkmıştır. Çünkü valilik kararı gereğince Derik Kaza Müdürü Hasan Ağa’nın söz konusu kişileri tekrar aza tayin ettiği 
bilgisine ulaşılmıștır. Ancak daha önce de belirttiğimiz gibi büyük meclis azalarının bu karardan haberlerinin olmadığı anlaşılmaktadır (BOA, İ.MVL 484/21943; 15/2). Nitekim Reşit'in ölümü sonrasında gönderilen Mayıs 1861 tarihli büyük meclis mazbatasında, Reşit'in azalıktan ihraç edilmesine ve kendi işiyle meşgul iken ahalinin niçin kendisine saldırdığı ve ölümüne neyin sebep olduğunun araştırılmasının istenmiş olması da bu iddiayı doğrulamaktadır (BOA, İ.MVL 484/21943). Ayrıca söz konusu olaya neden olan aşar maddesine dair Derik Kazası Müdürü Hasan Ağa'ya yazdığı tahriratta Hacı Şeyh Ağa'nın suçlamaları kabul ettiği anlaşılmaktadır.

Hacı Şeyh Ağa Beşiri kazasında da Derik kazasındaki usulsüzlüklere benzer nedenlerle suçlanmıştır. İddiaya göre burada da ağnam vergisi dahilinde sagir inekten vergi alınmıştır. Söz konusu olay kaza naibi Derviş Efendi'nin hükümete haber vermesiyle anlaşılmıştır. Bu nedenle de Hacı Şeyh Ağa Derviş Efendi'yi azlettirmiştir (BOA, İ.MVL 627/78-2). Nitekim bu kapsamda yapılan soruşturmada Beşiri Kazası'nın 1277 (1860/1861) senesi adet-i ağnam vergisinin Ağa'nın damadı Laçin Bey'le Mehmet Ağa üzerinde olması nedeniyle mültezim-i sanileri Hacı Şeyh A ğa'ya güvenerek sagir inekten dahi ağnam resmi aldıklarını kabul etmişlerdir (BOA, İ.MVL 484/21943). A ğa burada da Kaza Meclisi'nden bazılarını azlettirip kendi istediği kişileri getirtmiştir. Hacı Şeyh Ağa söz konusu suçlamaları kabul etmiştir (BOA, İ.MVL 484/21943).

Hacı Şeyh Ağa'nın usulsüz atama yaptırdığı diğer yerler Şirvan ve Garzan'dır (BOA, İ.MVL 484/21943). Şirvan Kazası müdürü Şir Bey ve Garzan Kazas1 müdürü Abdulfettah Beylerin, haklarındaki şikayet nedeniyle Diyarbakır'a gönderilmesi Siirt Kaymakamı'na bildirilmiştir. Ancak bu girişimden bir sonuç alınamaması üzerine büyük meclis azası sıfatıyla Hacı Şeyh Ağa bu işle görevlendirilmiştir. Bu sırada Şir Bey'in Erzurum tarafina gittiği yönünde bilgi elde edilmişti. Hacı Şeyh Ăga'ya verilen talimatta eğer Şir Bey, Erzurum tarafına gitmiş ise yakalama kararının yakınlarına ve adamlarına karşı uygulanması gerektiği ifade edilmiştir. Fakat Hacı Şeyh Ağa'nın Siirt'e ulaşmasından bir gün sonra Abdulfettah Bey Diyarbakır'a gelmiştir. Şir Bey'in ise Diyarbakır'da yargılanmak istemediği için İstanbul'a gittiği anlaşılmıştır (BOA, İ.MVL 484/21943). Şir Bey'in İstanbul'a yargılanmak istemesinin nedeni bir başka belgede açıklığa kavuşmaktadır. Bu belgeye göre Hacı Şeyh Ağa, kendilerine karşı düşmanlık etmektedir ve adil bir yargılama yapılmayacağını düşünerek İstanbul'a gitmeyi tercih etmiştir (BOA, İ.MVL 627/78).

Yukarıda sözünü ettiğimiz talimata rağmen Hacı Şeyh Ağa Siirt'e gider gitmez Garzan Kazası'na Hamid Bey'i, Şirvan'a ise ömür boyu sürgün cezası ile Vidin'de bulunan Sait Bey'in oğlu Şirvanlı Hurşit Bey'i müdür tayin etmiştir. 22 Mayıs 1862 tarihli konuyla ilgili yapılan soruşturma kaydında olaydan bir buçuk ay sonra Hurşit Bey'in geçici olarak Şirvan'a, Hamid Bey'in asaleten Garzan'a atandığına dair 12 Mart 1861 tarihinde Diyarbakır Büyük Meclisi'nden mazbata gönderildiği bilgisi yer almaktadır. Bu atamaları Hacı Şeyh Ağa'nın gücünü yerel otorite üzerinde kullanarak gerçekleştirildiği anlaşılmaktadır. Hacı Şeyh Ağa, bu tayinleri de liva meclisinin onayı olmaksızın yapmıştır. Ayrıca yine Liva Meclisi'nde karar alınmadan asker toplamış ve Şir Bey'in oğlu Osman Bey'i ise Siirt'e uygunsuz bir şekilde göndermiştir. Şir Bey ve Abdulfettah Beye karşı elini güçlendirmek için halkı kışkırtarak arzuhaller yazdırıp göndermiştir (BOA, İ.MVL 484/21943). Yine arşiv kaydından anlaşıldığ üzere Garzan'a müdür olarak atadığı Hamid Bey'in Hacı Şeyh Ağa'nın beklentilerini tam olarak karşılayamadığından bir süre sonra azl edilerek yerine Hacı Şeyh Ağa'nın akrabası olan Yusuf Efendi atanmıştır. Yusuf Efendi'nin faaliyetleri sonucu bölgede huzursuzluk çıkmıştır (BOA, MVL 627/78). Bir başka arşiv kaydına göre de Hacı Şeyh Ağa'nın Abdulfettah aleyhine bölgede yaptığı çalışmalar işe yaramış görünmektedir. Nitekim Garzan'da bulunan rahip ve dört kişinin kışkırtması dolayısıyla Abdulfettah'ı Diyarbakır'da sekiz ay hapsettirmiştir. Diyarbakır valisine yazılan 28 Şubat 1862 tarihli yazıda bu durumun 
büyük meclis tarafından aydınlatılması istenilmektedir (BOA, A.MKT.UM 542 /95). Hac1 Şeyh Ağa bu konuyla ilgili sorgusunda müdürlerin tayinini valinin emriyle gerçekleştirdiğini ifade ederek, yukarıda kendisine verilmiş olan talimata aykırı davrandığını kabul etmiş görünmektedir (BOA, İ.MVL 484/21943).

Hacı Şeyh Ağa'ya atfedilen suçlardan bir diğeri de 1861 senesinde bazı köylerin Arap aşiretleri (aşair-i urban) tarafindan tahrip ve yağma edilmesine sebep olmaktır (BOA, MVL 627/78; BOA, A.MK.DV 117/81).

Hacı Şeyh Ağa hakkındaki bir diğer suçlama ise Diyarbakır'ın Bahaüddin Mahallesi ahalisinden Molla Hasan bin Mehmet'e aittir. 3 Haziran 1857 tarihli bir belgedeki iddiaya göre Hacı Şeyh Ağa, Molla Hasan'ı hırsızlık suçuyla hapse attırmış ve 21 ay sonra (BOA, İ.MVL 484/21943) rahatsızlandığı için kefaletle salıvermiş ve bunun karşılığında kendisinden 500 adet mecidiye altını istemiştir. Olayın yaşandığ 1 tarihten bir yıl sonra 250 adet altını toparlayarak Hacı Şeyh Ağa'nın konağına götürmüş ve Ağa 500 altına anlaştıklarına vurgu yapmasına rağmen altını almış ve söz verdiği gibi Molla Hasan'1 hapis cezasından kurtarmıştır. Molla Hasan, Hacı Şeyh Ağa'nın konağına Tacir Mehmet ve Tacir Ali ile birlikte gitmiştir. Hatta Hacı Şeyh Ağa'nın bu adamlar kim sorusu üzerine güvenilir olduklarını belirtmiştir (BOA, İ.MVL.484/21943). İşte bu olayın gerçekleştiğini ve para verdiğini iddia eden Molla Hasan, söz konusu kişileri de şahit göstererek verdiği altınları talep etmiştir. Şahitlerin de bu yöndeki ifadeleri doğrultusunda Hacı Şeyh Ağa'nın Molla Hasan'dan aldığ 250 adet mecidiye altını iade etmesine karar verilmiştir (BOA, İ.MVL.484/21943). Ancak daha sonra Hacı Şeyh Ağa bu şahitlerden Mehmet ve Ali'nin yalancı şahit olduklarını iddia ederek davacı olmuştur. Hacı Şeyh Ağa'nın, yolsuzluk, rüşvet ve halka karşı uygunsuz davranışları nedeniyle tutuklanmasından sonra 24 Ocak 1863 tarihli bir yazıda, Ağa hakkındaki iddiaların asılsız olduğu, şahitlerin yalancı şahit oldukları ve ailesinin zor duruma düştügü ileri sürülmüştür (BOA, MVL 412/63). Bu hususta Hac1 Şeyh Ağa'nın yeni bilgi ve belgeler sunması üzerine Meclis-i Vala, davanın tekrar büyük mecliste görülmesine karar vermiştir. Diyarbakır meclisinde yapılan yeni tahkikatta Tacir Ali, Hacı Şeyh Ağa'nın rüşvet aldığına dair ifadesinde 1srar etmiştir. Hatta yalancı şahit olduklarına dair meclis tarafından düzenlenmiş mazbatadaki mührün kendisine ait olmadığını belirtmiştir. Zaten bu evrakta üçü mühürsüz, 15 ise mühürlü şahsın ismi mevcuttu. Bunlardan altısı sadece Tacir Mehmet'in sözlerine şahit olduklarını ancak Tacir Ali'yi görmediklerini ve senette sadece Mehmet'in mührünü ve imzasını gördüklerini beyan etmişlerdi. Mührü olmayanlardan birisi Mehmet'in söylemlerine şahit olduğunu ve senedi görmediğini ifade ederken, diğer dokuz kişi ise Tacir Mehmet ve Tacir Ali'nin sözlerine şahit olduklarını belirtirken, biri de Tacir Ali'den bu konuda söz işittiğini ancak düzenlenen senedin neyle ilgili olduğunu bilmediğini ifade etmişti. Senette mührü bulunmayanlardan biri de o tarihte Diyarbakır'da olmadığı için ifadesi alınamamıştır. Nitekim sorgulamada senedi Hacı Şeyh Ağa'nın damadının hazırladığ 1 şahitlerin Hacı Mehmet'in imzasını gördükten sonra ve takririni alıp mühürledikten sonra Ali'nin imzasının atıldığını itiraf etmişlerdi. Tacir Ali'nin yalancı şahit olduğunu iddia edenlerin Hacı Şeyh Ağa'nın yakınları olması sebebiyle, 250 mecidiye altının rüşvet olduğu yönündeki iddianın doğru olduğunu kabul edilmiştir. Bu konuda verilen ceza Hacı Şeyh Ăğa'nın aldığı en ağır cezayı teşkil etmiştir (BOA, İ.MVL 484/21943).

\section{Hacı Şeyh Ağa'ya Verilen Ceza}

Sözlük anlamı olarak bir şeyin karşılığını ifade eden ceza, hukuksal olarak suçluya uygulanacak maddi ve manevi yaptırımı ifade eder (Bebek, 1993, s. 469). Tanzimat ile birlikte her alanda olduğu gibi ceza hukuku alanında da düzenlemeler yapıldı. 1840, 1851 ve 1858 tarihlerinde yapılan üç kanunnamede ceza hukuku alanında bir takım yeniliklere yer verilmiştir (Aydın, 1993, s. 481-482; Üçok, 2007, s. 343-344). 
Hacı Şeyh Ağa ile ilgili soruşturmalarda suçlu bulunanlara 1858 Ceza Kanunnamesi'ne göre cezalar verilmiştir. Cezalarla ilgili olarak aşağıda vereceğimiz bilgilere göre Diyarbakır genelindeki yolsuzluk ve rüşvet olayının başaktörü büyük meclis azası Hacı Şeyh Ağa'dır. Hatta bu davaya çıkar ilişkileri gereğince pek çok kişi dahil olmuştur. Belgelerden tespit edebildiğimiz kadarıyla başta Hacı Şeyh Ağa olmak üzere diğer suçlulara hangi cezaların verildiği ve cezaların nasıl uygulandığına dair bilgiler şunlardır:

Arşiv kaydında Hacı Şeyh Ağa'nın 4 Nisan 1862 'de tutuklandığı bilgisi yer almaktadır (BOA, MVL 655/28-2). 6 Nisan 1862'de Diyarbakır valisine gönderilen yazıda soruşturmanın başlatılması gerektiği bildirilmektedir (BOA, A.MKT. UM 551/90). Nitekim Hacı Şeyh Ağa davası ile ilgili Diyarbakır valiliğince gönderilen yazıda 28 Mayıs 1862'de soruşturmanın büyük ölçüde tamamlandığı ve verilecek karara kadar Hacı Şeyh Ağa'nın hükümet konağında tutulacağ1 belirtilmektedir (BOA, İ.MVL 484/21943). Kasım 1862 tarihinde Diyarbakır valiliğine gönderilen yazıdan cezanın kesinleştiği anlaşılmaktadır (A. MKT.MHM 272/29). Hacı Şeyh A ğa'nın ceza kanunun hangi maddelerine göre cezalandırıldığı ile ilgili bilgiler ise Nisan 1863 tarihli belgede yer almaktadır. Buna göre Hacı Şeyh A ğa, 1858 Ceza Kanunnamesi'nin 36, 68, 77, 108 ve 207 Maddeleri $^{2}$ gereğince cezalandırılmıştır (BOA, İ.MVL 484/21943). Nitekim Hacı Şeyh Ağa'nın ceza kanunnamesinin 68. maddesi gereğince almış olduğu rüşvetin iki katını ödemesine; kanunnamenin 77. maddesi gereğince bu paradan Molla Hasan'dan alınan kısmın iadesine ve kalan miktarın ise mal sandiğına teslim edilmesine; kapıcıbaşılık rütbesinin alınmasına; 36. maddeye istinaden de altı yıl süreyle rütbe ve memuriyetten men edilmesine karar verildi. Ayrıca uygunsuz davranışları ve Diyarbakır'da kalması münasip olmayacağı için de beş yıl Erzurum'a kalebent olarak sürgün edilmiştir (BOA, İ.MVL 484/21943).

Hacı Şeyh Ağa, tutuklandıktan dört ay sonra Nisan 1862'de sağlık sorunları nedeniyle kefile bağlanarak geçici olarak salıverilmiştir. İki ay içinde sağlığına kavuşmasına rağmen Nisan 1863 tarihine kadar serbest kalmıştır (BOA, MVL 655/28). Gerek Hacı Şeyh Ağa'nın ve çevresinin bu süreçte sergilediği tavırlar gerekse halkın onlara duyduğu güvensizlik halk1 bu konuda önlem almaya yöneltmiştir. Arşiv kayıtlarından anlaşıldığı üzere halk Hacı Şeyh Ağa'yla ilgili endişelerini her türlü mercide dile getirmiş ve yazılı olarak ilgili makamlara iletmişlerdir. Bu şikayetlerden biri de o sırada bölgede bulunan teftiş memuruna yapılmıştır. Bilindiği gibi Tanzimat yeniliklerinin doğru şekilde uygulanıp uygulanmadığının denetimini yapmak üzere yapılan "teftiş̧” uygulamasına 1863 'de yeniden başvurulmuştur (Tural, 2004, s. 101). Bu dönemde Anadolu ve Rumeli'ye gönderilmek üzere dört teftiş memuru görevlendirilmiştir. Diyarbakır söz konusu memurlardan biri olan Ali Rıza'nın teftiş bölgesi içeresinde bulunmaktadır (Serbestoğlu, 2013, s. 206-207). Nitekim Hacı Şeyh Ağa'nın davasının devam ettiği süreçte teftiş memuru Ali Rıza'nın bölgede bulunduğu belgelerden anlaşılmaktadır. Ali Rıza Efendi'nin 26 Temmuz 1863 tarihinde merkeze gönderdiği yazıda Süryani Patrikliği'nce kaleme alınıp kendisine gönderilen beyannameden hareketle Hacı Şeyh Ağa'nın bölge halkı üzerindeki olumsuz etkilerinden söz etmekte ve Diyarbakır'a ulaştığında olayla ilgili gerekli soruşturmaları yapacağını ancak şimdilik Hacı Şeyh Ağa'nın Erzurum'a gönderilmesinin uygun olacağını bildirmiştir (A. MKT.MHM 272/29). Ali Rıza Efendi'nin İstanbul'a gönderdiği yazı Temmuz 1863 tarihli olduğuna göre, çeşitli cezalara çarptırılan Hacı Şeyh Ağa’nın henüz sürgün yeri olan Erzurum'a gönderilmediği anlaşılmaktadır (A. MKT.MHM 272/29).

Ali Rıza'nın neden Hacı Şeyh Ağa’yı Erzurum'a gönderilmesini istediği ise Süryani patriğince yazılan beyannameden izlenebilmektedir. Buna göre Hacı Şeyh Ağa "kefile rabt" edilerek sağlık gerekçesiyle serbest bırakılmış ise de halk buna inanmamaktadır. Hatta ahaliye

\footnotetext{
${ }^{2}$ Söz konusu maddeler için bkz. Düstur-1 Atik, sene 1279, s.90-91; 99; 100; 108;130.
} 
göre Hacı Şeyh Ağa yeniden idarede etkin olmanın ve halk üzerinde baskı kurmanın yollarını aramaktadır. Ayrıca Ağa'nın adamları halk üzerinde baskı oluşturacak bir takım davranışlar sergilemişlerdir. Nitekim söz konusu beyannamede olaylar örnekleriyle anlatılmıştır. Buna göre Ağa'nın akrabaları olan Laçin Bey, Hacı Mehmet Ağa, Süleyman vb. kişiler sokaklarda “A ̆ga, Diyarbakır'a kaymakam olacak" gibi çeşitli söylemlerde bulunup, İstanbul'dan gelen her posta ile halkı daha da panik havasına sokmuşlardı. Hatta merkezden kendilerine bildirildiğini iddia ettikleri "şu kişi sürgün edilecektir, şu şekilde cezalandırılacaktır" gibi yalan beyanlarla halk üzerinde baskı kurmaya çalışmışlardır. Bunun yanı sıra Ağa'nın konağından sahte mühürlerle çeşitli yazılar yazarak güç gösterisine devam etmişlerdi. Yine Hacı Şeyh Ağa'nın zimmet-i miriyesini vermeme konusundaki 1srarından hareketle Ağa'nın cesareti sorgulanmıştır. Ayrıca Diyarbakır Meclis azalarından bazılarının Ağa'yı kurtarmak istediği dile getirilmiştir. Meclis azası Hacı Nuh Ağa'nın Hacı Şeyh Ağa'ya yardım ettiği ve onu kurtarmak için aktif olarak çalıştığ 1 örneklerle açıklanmıştır. Ahalinin tam olarak duydukları rahatsızlık "Bu adamın Hacı Şeyh Ăga'yı kurtarayım deyu neler yaptığ tarife gelmez. Böylelerin yüzünden Devlet-i 'Aliyye'nin tebaa ve reayası harap oluyor. Arzuhal etmeye mukteza-l sitkl çakeri kendimi borçlu bildim. Ihsan buyurup bu zalimlerin ellerinden bu havali fukarasını halas buyurasınız. Bunlardan Allah'a sığındık. Memlekette emniyet kalmadl" sözleriyle ifade edilmiştir (A. MKT.MHM 272/29).

Hacı Şeyh Ağa'nın iltizamlar üzerinde yaptığı usulsüzlüklere dikkat çekilerek damadını 1863 yılı için mültezime ortak yaptırdığı ve gücünü topladıktan sonra yeniden uygunsuz davranışlarına ve usulsüzlüklere başlayacağı dile getirilmiştir. Yine Hacı Şeyh A ğa'nın büyük meclis azası olduğu dönemde Derik'e müdür tayin ettirdiği ve görevden azledilmiş olan Hacı Hasan Ağa'nın, onun adamı Hacı Nuh Ağa tarafından yeniden müdür tayin ettirilmeye çalışıldığına dikkat çekilerek, bunun gerçekleşmesi halinde halkı zor günlerin beklediğine vurgu yapılmıştır (A. MKT.MHM 272/29).

Süryani Patriği’nce kaleme alınan beyanname Hacı Şeyh Ağa ve taraftarlarının bölgede eski otorite ve işbirliğini kurabilmek için çeşitli çalışmalar içinde olduğunu göstermektedir. Ağa'nın rahatsızlığı nedeniyle evinde olması rahat hareket etmelerine ve istediklerini yapma cesaretini vermektedir. Dolayısıyla durumdan rahatsiz olan halk bu konuda yaşadıkları korku ve kaygılarını her türlü mercide dile getirmiş ve yazılı olarak ilgili makamlara iletmişlerdir.

Halkın başvuruları ve endişeleri dikkate alınmış olmalı ki Hacı Şeyh Ağa'nın 27 Haziran 1863 tarihinde daha önce hapiste kaldığı süre göz önünde bulundurulmak ve kalan süresini çekmek üzere Erzurum'a gönderilmesine karar verilmiştir (BOA, MVL 655/28). Nitekim Hacı Şeyh Ăga'nın 16 Ağustos 1863 tarihinde hapiste olduğu tespit edilmektedir (BOA, MVL 658/2).

Halk Hacı Şeyh Ağa'nın ifade edilen davranışlarından şikayetçi olurken, Ağa'nın karısı ve taraftarları ise tam tersi iddialarda bulunarak affedilmesini istemekteydiler. Onlara göre kefaletle serbest kaldığı süre boyunca Ağa'nın Diyarbakır'dan ayrılmasına izin verilmemiş, sadece camiye kadar gidip gelmesine müsaade edilmişstir (BOA, MVL 512/23095).

\section{Olaylara Karışanlara Verilen Cezalar}

Dava konularından birisi Derik Kazası meclis azaları Reşit Kethüda ve Seyithan'ın uygunsuz davranışları nedeniyle azledilmeleri ve Hacı Şeyh A ğa tarafından hileyle tekrar meclis azası tayin edilmelerine dairdi. Bilindiği gibi bu olaylar sonrası Reşit Kethüda ölmüş ve akrabalarından bazıları yaralanmıştı. Reşit Kethüda'nın ölümünden sorumlu tutulan Aziz, Osman ve Mustafa sorgulanmıştır (BOA, MVL 606/41). 17 Mayıs 1861 tarihli bir belgeye 
göre olayda adı geçen şahısların çeşitli cezalara çarptırıldıkları anlaşılmaktadır. Buna göre birinci derece olaya müdahil olanlara on beşer, ikinci derecedekiler onar ve üçüncü derecede olanlara ise beşer yıl Ergani Madeni'nde çekmek üzere kürek cezası verilmiştir. Yine aynı belgeden anlaşıldığı üzere olayda suçları tespit edilemeyen dört kişi ile Reşit Kethüda'nın tekrar meclis azası tayin edilmesine dair kararı neden hükümete bildirmediğini izah edemeyen ve senedi kaleme alan Molla Mehmet hakkında yeni bir soruşturma yapılmasına karar verilmiştir.

Diğer suçlulardan altısı vefat etmiş ve ikisi de firari durumdadır. Ayrıca 29 kişi de Ergani Madeni'nde kürek cezasına çarptırılmıştır. Aynı belgede Molla Mehmet'in hükümete haber vermemesinin gerekçesi olarak korktuğu ifade edilirken, sabıkasının olmadığı ve "biçare fukara" olduğu belirtilmiştir (BOA, MVL 611/60) .Yine 28 Haziran 1861 tarihli belgede 20 kişinin Ergani Madeni'ne gönderildiği, senedi yazan Molla Mehmet'in hapis yattığı süre de göz önünde bulundurularak tahliyesinin uygun olduğu bilgisi yer almaktadır (BOA, MVL 611/60).

Hacı Şeyh Ağa'nın rüşvet olayının muhatabı Molla Hasan ise kendisini korumak adına bask1 ve korku ile rüşveti verdiğine kanaat getirildiğinden daha önce de değindiğimiz gibi Ceza kanunnamesinin 77. Maddesi gereğince rüşvet olarak verdiği parayı geri almış ve suçsuz bulunmuştur (İ.MVL 484/21943). Yine bu olayda Hac1 Şeyh Ağa lehine yalancı şahitlik yapan Mehmet'in 207. maddeye (Bkz. Düstur-1 Atik, 1279, s. 130) göre hapis tarihinden itibaren 19. Madde (Bkz. Düstur-1 Atik, 1279, s.87) de yer alan uygulama gereğince 3 yıl Ergani Madeni'nde kürek cezasına çarptırılmıştır (BOA, MVL 611/60).

Beşiri Kazası'nın ikinci mültezimi Hacı Timur Kahya, sagir inekten dahi aşar vergisi alması nedeniyle yapılan tahkikatta suçlu bulunmuştur. Bu nedenle ceza kanunnamesinin 108. Maddesinin ikinci hükmünce tutuklandığı tarihten itibaren iki sene hapis cezasına çarptırılmış ve usulsüz olarak aldığı aşar vergisinin bir katının alınmasına karar verilmiştir (BOA, MVL $611 / 60)$

\section{Af Talepleri}

Hacı Şeyh Ağa'nın kefile rabt ile serbest olduğu dönemde İstanbul'a iftiraya uğradığına dair yazılar gönderildiği anlaşılmaktadır. Nitekim 15 Ekim 1862 tarihli belgede Ağa'ya yapılan suçlamaların iftira olduğu ve yalancı şahitlerle Hacı Şeyh Ağa'nın tutuklandığı iddia edilerek Meclis-i Vala'da yeniden yargılanması talep edilmektedir (BOA, MVL 403/31). Bundan yaklaşık üç ay sonra 24 Ocak 1863 'de yine bu yazıya benzer ifadelerle Hacı Şeyh Ağa'nın iftiraya uğradığ 1 ve boş yere yaklaşık 10 ay hapis yattığı vurgulanmıştır (BOA, İ.MVL 412/63). Şubat 1863 tarihli bir diğer belge de ise haksızlığa uğradığı, affedilmesi ve meclis üyeliğine yeniden tayin edilmesi istenmiştir (Ueno, 2013, s. 98; BOA, MVL 645/1). Hacı Şeyh Ağa'nın cezasını çekmek üzere Erzurum'a gönderilmesinden sonra iftiraya uğradığına dair yazıların arkası kesilmemiştir. Bunlardan biri de 16 Ağustos 1863 tarihli yazıdır. Bu yazıda Hacı Şeyh Ağa'nın meclis azalığı görevinde bulunduğu sürede halkın huzuru için çalıştığı, görevini kanunlar çerçevesinde yerine getirdiği, halk üzerindeki etkinliği ve Hristiyan halkın Ağa'dan memnuniyetine vurgu yapılarak Erzurum'da çürümesi haksızlık olarak nitelendirilmiş ve Ağa'nın tekrar Diyarbakır'a getirilmesi talep edilmiştir (BOA, MVL 658/2).

Tanzimat döneminde yöneticilerin dava örneklerinde olduğu gibi (Bkz. Saydam, 2020, s. 2574) söz konusu dava da Hacı Şeyh Ağa'nın yakınlarının af talebini dile getirdikleri görülmektedir. Nitekim 4 Mart 1864'te eşi tarafından affedilmesi talebiyle gönderilen kayıtta yukarıda değinilen yazılardaki benzer ifadeler yer almaktadır. Belgede yine suçların iftira olduğu ve yalancı şahitlikten söz edilmektedir ancak burada açıç̧a af talebi dile getirilmektedir. Yazı Hacı Şeyh Ağa'nın Erzurum'a sürgün edilme kararından sonra 
yazılmıştır. Hastalığı, yaşı (70) ve ailesinin perişanlığ 1 dile getirilerek affedilmesi istenmektedir (BOA, MVL 512/23095). Ancak Hacı Şeyh Ağa'nın ve yakın çevresinin ne yeniden yargılanma ne de çeşitli gerekçelerle öne sürdükleri af talepleri kabul edilmemiştir. Nitekim 5 Haziran 1864 tarihli belgeden Hacı Şeyh Ağa'nın yaşı ve ailenin perişanlığ nedeniyle af talebinin kabul edilmediği bilgisi yer almaktadır. Açıklamada kalebent cezası almış kişilerin cezalarını tamamlamaları gerektiği belirtilerek ailesinin mağduriyetinin giderilmesine karar verildiği vurgulanmaktadır (BOA, MVL 674/28).

\section{Soruşturmaya Dair}

Nizamiye mahkemeleri kuruluncaya kadar daha önce de belirtildiği üzere davalar Meclis-i Tahkik, Büyük Meclis, Meclis-i Vala sistemi içinde çözülmüştür. Konumuz olan davanın da bu sistem içinde çözüldügü arşiv kayıtlarından görülebilmektedir. Nitekim 6 Nisan 1862 tarihli şikayetler doğrultusunda Anadolu Ordusu Müşirliği, Seraskerlik makamı ve Babıali'ye gönderilen yazı ve belgelere istinaden Meclis-i Vala'nın konunun araştırılmasına karar verdiği, yapılacak tahkikat sonunda Hacı Şeyh Ağa'nın suçlu bulunması halinde dava dosyasının İstanbul'a gönderilmesi gerektiği bilgisine yer verilmiştir (BOA, A. MKT.UM $551 / 90)$

Dava sürecinin nasıl işlediğine dair bilgiler dava dosyalarından izlenebilmektedir. Buna göre olayla ilgili araştırma yapılmakta, davalıların sorgularına göre sorular düzenlenmekte ve gerektiğinde yeniden ifadelerine başvurulmaktaydı. İfadelerde isimleri geçenler var ise onlar da sorgulanmıştır. Ayrıca farklı ifadeler ya da durumlar ortaya çıkmışsa ilgili tarafların bu konuyla ilgili görüşlerine yeniden başvurulmuştur. Herhangi bir belge varsa sorgusu yapılan ilgili kişinin fikri alınmakta ya da bahsedilen bir yazı ya da belge olduğu söylenmişse doğruluğu araştırılıp dosyaya eklenmekteydi. Eğer resmi bir kayıtsa söz konusu belge ilgili yerlerden talep edilmekteydi (Sivrikaya, 1972, s. 143-144). Çalışmamız kapsamında incelediğimiz dava dosyasında yer alan ifadeler tam olarak bu açıklamalarla uyuşmaktadır. Soruşturmanın büyük bir titizlikle sürdürüldüğü görülmektedir. Arşivde bulunan dava dosyasından soruşturmanın detayları izlenebilmektedir. Örneğin Seyithan ve Reşit Kethüda'nın azalığa yeniden atanmalarına dair tahkikatta o sırada meclis azası olmaları sifatıyla Resul, Sinan ve İsmail'in ifadesine başvurulmuştur. Mahkeme tarafindan "Mukaddema Reşit ve Seyithan'ın aleyhine gelen mahzarda sizin dahi mührünüz olduğu gibi lehine olan ve bunun azalığını isteriz mealinde bulunan memhur, senet yollu arzuhalde dahi mühürleriniz vardır. Böyle mübâyin senet yollu şeyler mühürlemenin hikmeti nedir?" tarzındaki sorularla başlayan soruşturma evrakı şöyle devam etmektedir:

Cevap: Sebebi tafsile muhtaçtır söyleyelim

Sual: Söyleyiniz

Cevap: Mukaddema yani 76 senesi evahirinde bizi buraya istediler.

Soru: Buraya sizi kim istedi

Cevap: Hacı Şeyh Ăga

Sual: Kimi gönderip istedi.

(.....)

Görüldüğü gibi verilen cevaba göre sorgu şekillenmektedir. Burada neden Diyarbakır'a çağnıldıkları sorgulanırken 1276 (1859-60) aşarını Hacı Şeyh Ăga'nın kendi adına toplatmak istediği, aşar iltizamını toplamak üzere tayin edilmiş mültezim olmasına rağmen niçin böyle davrandığ ve o dönem mukayyid olan Veli Efendi'nin konuyla ilgili bilgisinin olup olmadığ sorusu yöneltilmiştir. Daha sonra Derik Kazası müdürü Hasan Ağa sorgulanmıştır. Hasan 
Ağa'nın 2 Mayıs 1862 tarihli sorgusunda, H. 1276 (M.1859-60) senesi aşar konusu gündeme gelmiştir. Bunun üzerine Hasan Ağa'nın, “birer birer sual ediniz, söyleyeyim” demesi üzerine o sene mültezimin kim olduğu, mültezimin ortağının olup olmadığg, hazinenin tayin ettiği mültezim varken nasıl başkasına ihale olunduğu gibi sorular sorulmuştur (İ.MVL 484/219435). Dava dosyası bu şekilde sürüp gitmektedir. Belgeden anlaşıldığına göre verilen ifadelerin doğruluğu ya da uygulamayla örtüşmeyen durumları netleştirmek için yetkisi ve bilgisi olan kişilerin ifadesine başvurulduğu anlaşılmaktadır. Yukarıda değinilen dava sürecinde ilgili belgelere ulaşılarak verilen cevapların teyit edildiğine dair örnekte olduğu gibi Hacı Şeyh Ağa'nın davasında da ilgili belgelerin nerede olduğu sorgulanmıştır. Hatta 20 Nisan 1862 tarihinde kaza müdürü Hasan Ağa'nın daha öncede değinildiği gibi Reşit ve Seyithan'1 valinin emirnamesine göre atadığını söylemesi üzerine mahkemece emirnamenin nerede olduğu sorulmuş ve ilgili belge getirtilerek verilen cevabın gerçekliği teyit edilmiştir (İ.MVL 484/21943). Ayrıca davalıların yüzleștirilme örneklerine de dava dosyasında yer almaktadır. Sorular ve cevaplar oldukça anlaşılır, net genel olarak kısa niteliktedir. Davalılar kimi zaman "bilmem", "hayli zaman geçti", "hatırımdan çıkmıştır" gibi cevaplarla soruları geçiştirmektedir (İ.MVL 484/21943).

Fiziksel olarak dosyayı değerlendirdiğimizde ise dava dosyasında yer alan açıklayıcı bilgiler olayların takibini sağlamaktadır. Nitekim ifadesine başvurulan şahsın ismi belirtilerek "Sual Tevcih Etmekle Istintak" edildiği belirtilmiştir. Eğer kişinin yeniden sorgulanmas1 gerekmişse bu kez sorgulama nedeni de bu ifadeye eklenmiştir. Yine sorgulanacak kişinin hazır bulunmadığı durumlarda zaman kaybedilmediği yerine konuyla ilgili diğer kişinin sorgulamasına başlandığı ifadelerden önce verilen açıklayıcı bilgilerden anlaşılmaktadır. İfadelerin birlikte alındığı durumlarda hangi sorudan sonra ayrildı̆̆ da net olarak verilmektedir. Kimi durumlarda şerhler de düşüldüğü görülmektedir.

İfadeler daha önce de değinildiği gibi soru cevap şeklinde alınmaktadır. Soru-cevap olarak yapılan sorgulamaların takibini sorulara verilen numaralar kolaylaştırmaktadır. Nitekim dava sürecinde de kimi zaman bu soru numaralarına atıflar yapılarak açıklayıcı bilgiler verilmektedir. İncelediğimiz davada farklı suçlamalar olduğu için her bir suçlama için ayrı bir soruşturma yürütülmüş ve bunlar yeni dava konusu gibi ayrı ayrı numaralandırılmıştır.

\section{Sonuç}

Tanzimat döneminde rüşvet ve yolsuzluğa dair alınan önlemler ve uygulamalar çerçevesinde önemli olan verilerden biri de bu süreçte çokça örneğine rastladığımız rüşvet davalarıdır. Bu anlamda çalışmamıza yön veren Diyarbakır Meclis Azası Hacı Şeyh Ağa'nın davası yerel bazda yaşanan aksaklıkların tespitleri açısından önemli veriler sunmuştur. Nitekim Tanzimat dönemi uygulamalarında eksiklik ve reformların başarısız olmasının sebebi olarak ifade edilen eğitimli insan ve idareci bulunmadığı iddiası Hacı Şeyh Ağa örneğiyle teyit edilmiştir. Çünkü dava dosyasında yer alan verilere göre Ağa'nın meclis azalığının verdiği yetki ve bölge halkı üzerindeki kişisel gücünü kendi çıkarları için kullandığ anlaşılmaktadır. Bölge halkı durumundan rahatsızlık duysa da Ağa'nın yerel yönetimindeki ağırlığından dolayı sessiz kalmayı tercih etmiştir. Ne zaman ki Ağa'nın yaptığı uygunsuzluklar gündeme gelmeye başlamış halk da rahatsızlığını çeşitli aracılarla merkeze ulaştırmaya çalışmış ve başarılı olmuştur.

Hacı Şeyh Ağa özellikle vergiler üzerinden kazançlar sağlamaya çalışmış ve bunun için kendi çıkarında kullanacağı adamları atamış hatta Derik Kazası azaları örneğinde olduğu gibi halka ve yönetmeliklere rağmen uygunsuz bir şekilde görevden alınan kişileri atamıştır. İşlerini yaptırmaya ikna edemediği kişileri de korkutarak otoritesini yerel yönetim üzerinden sağlamıştır. Ayrıca akrabalarını da kullanarak sadece Diyarbakır merkezde değil bölge üzerinde çıkar sağlamaya yönelik girişimlerde bulunmuştur. Özetle Hacı Şeyh Ağa çıkarını 
korumak için görevinin kendisine tanıdığı ayrıcalıkları sonuna kadar kullanmıştır. İstediğini elde edebilmek için tehdit, hile gibi yöntemlere başvurmuş ve bunları da alenen yapmaktan çekinmemiştir.

Tanzimat dönemi aksaklıklarının yanı sıra çalışma konusu olan dava, nizamiye mahkemeleri kurulmadan önce yolsuzluk ve rüşvet davalarının işleyişini değerlendirme imkanı vermektedir. Nitekim yerel bazda kurulan meclislerin işleyişindeki aksaklıkların bir nedeni olarak üye seçimlerinin önemini göstermesi açısından önemli olmuştur. Tutanakları görme şansını yakaladığımız dava dosyasında soruşturmanın işleyişine dair ayrıntılı bilgilere ulaşılmaktadır. Tutanaklarda yer alan ifadeler ve sorular sorgulanan kişilerin söylediği her şeyin netleştirilmeye çalışıldığını göstermektedir. Bu soruşturma kapsamında sorgulanan kişilerin ifadeleri Diyarbakır örneğinde taşrada yaşanan yolsuzluk ve yönetimin eksikliklerini ortaya koymaktadır. Ayrıca Diyarbakır ölçeğinde Meclis-i Vala ve büyük meclislerin işleyişinin ortaya konulması açısından önemli veriler sunmuştur. 1858 Ceza Kanunnamesi'nde yer alan hükümlere uygun olarak davanın incelendiği ve kararların alındığı görülmektedir.

\section{Kaynakça}

\section{Başkanlık Osmanlı Arşivi}

İrâde Meclis-i Vâla (İ.MVL) 484/21943; 512/23095

Meclis-i Vala MVL 403/31;412/63;606/41;611/60;627/78;645/1;655/28;658/2

Sadaret Mektubi Kalemi Umum Vilayat Evrakı (A.MKT.UM) 542/95;551/90

Sadaret Mektubi Kalemi Deavi Evrakı (A.MKT.DV )117/81

Sadaret Mektubi Kalemi Nezaret ve Deva'ir Evrak1 (A.MKT.NZD) 410/15

Sadaret Mektubi Mühimme Kalemi Evrakı (A.MKT.MHM) 272/29

\section{Araştırma İnceleme Eserler}

Ahmed Lütfi Efendi, (1984). Vak'anüvis Ahmed Lütfi Efendi tarihi IX. (Yay. Münir Aktepe), İstanbul : İ.Ü. Edebiyat Fakültesi Matbaası.

Akgündüz, A. (1987, Nisan).1274/1858 tarihli Osmanlı ceza kanunnamesinin hukuki kaynakları, tatbik şekli ve men'-i irtikab kanunnamesi. Belleten. Cilt LI (Sayı 199), 153-193.

Akyıldız, A. (1993). Tanzimat dönemi Osmanlı merkez teşkilâtında reform. İstanbul: Eren Yay.

Al, H. (2005). Türk kamu yönetiminde yolsuzlukla mücadele: Geleneksel bürokratik yapı ve yeni etik değerler, Siyasette ve yönetimde etik değerler bildiriler kitabı (ss.239-249).

Aydın, M. A. (1993). Osmanlı ceza hukuku. DİA. Cilt VII, 1993, 478-482.

Bebek, A. (1993). Ceza. DIA. Cilt VII, 469-470.

Bingöl, S. (2004). Tanzimat devrinde Osmanlı'da yargı reformu. Eskişehir: Anadolu Üniversitesi Edebiyat Fakültesi Yayınları.

Bozkurt, G. (1996). Batı hukukunun Türkiye'de benimsenmesi (Osmanlı Devleti'nden Türkiye Cumhuriyeti'ne resepsiyon süreci, 1839-1939), Ankara: TTK

Cin, H. (1992).Tanzimat döneminde Osmanlı hukuku ve yargllama usulleri. 150. yılında Tanzimat (ss.11-32) Anakara: TTK.

Çadırc1, M. (1991). Tanzimat döneminde Anadolu kentlerinin sosyal ve ekonomik yapıları, Ankara: TTK.

Çadırcı, M. (2007). Osmanlı döneminde yerel meclisler. Tanzimat sürecinde ülke yönetimi, (ss.287-301), Ankara: İmge Kitabevi. 
Çadırcı, M. (1982) .Tanzimat'ın ilanı sıralarında Osmanlı İmparatorluğu'nda kadılık kurumu ve 1838 tarihli “tarik-i ilmîyye'ye dâir cezâ kanunname'si”, DTCF Tarih Araştırmaları Dergisi, Cilt XIV/25, 139-161.

Çelik, Y. (2006). "Tanzimat devrinde rüşvet - hediye ikilemi ve bu alandaki yolsuzlukları önleme çabaları" Türk Kültürü İncelemeleri, 15, 25-64.

Davison, R. H. (1997).Osmanlı Imparatorluğu'nda reform (1856-1876) I, (Türkçesi: Osman Akınhay), İstanbul: Papirus Yayınları.

Düstur-1 Atik, 1279.

Ekinci, E. B. (2004).Tanzimat ve sonrası Osmanlı mahkemeleri. Ankara: Arı Sanat Yayınevi. Fulin, N. ( 2019). Osmanlı'da rüşvet ve cezası. Akademik Tarih ve Araştırmalar Dergisi, Cilt 1 (Sayı 1), 26-35.

Kahraman, S.(2010. Türk kamu yönetiminde yolsuzlukla mücadelede hukuki ve idare düzenlemelerin etkisi, (Yayınlanmamış Yüksek Lisans Tezi). Kocaeli Üniversitesi Sosyal Bilimler Enstitüsü, Kocaeli.

Keleș, E. ( 2005). Tanzimat döneminde rüşvetin önlenmesi için yapılan düzenlemeler (18391858). Tarih Araştırmaları Dergisi, cilt 24 (Sayı 38), 259-280.

Keleş, E.(2019). Anadolu'da Tanzimat ve teftiş (1850-1853). Ankara: Gece Akademi. Mumcu, A. (1985).Tarih içindeki genel gelişimiyle birlikte Osmanlı Devleti'nde rüşvet (özellikle adlî rüşvet), İstanbul: İnkılâp Kitabevi.

Özsemerci, K. (2003).Türk kamu yönetiminde yolsuzluklar, nedenler, zararları ve çözüm önerileri, Ankara: Sayıştay Yayınları.

Saydam, A. (2020, Ekim) Edirne'de Tanzimat'ın ilk ayları ve vali Nâfiz Paşa'nın muhakemesi. History Studies, 12/5, 2557-2576.

Serbestoğlu, İ. (2014). Abdülaziz ve teftiş: Ali Rıza Efendi’nin Canik Sancağ1 Teftişi, Sultan Abdülaziz ve dönemi sempozyumu 12- 13 Aralık, 2013 (ss.204-225). Ankara: TTK. Seyitdanlıŏlu, M. (1994).Tanzimat devrinde meclis-i vâlâ (1838-1868). Ankara: TTK Sivrikaya, İ. (1972). Osmanlı Devletinde hukuk kaidelerinin gelişimi ve Tanzimat'tan sonraki uygulanışı. Güney-Doğu Avrupa Araştırmaları Dergisi. I, 139-146.

Taner, T.( 999).Tanzimat Devrinde Ceza Hukuku. Tanzimat 1 (ss.221-232). İstanbul: Milli Eğitim Bakanlığı Yayınları.

Tural, E. (2004, 2 Nisan). Bir belge 1861 Hersek isyanı, 1863 eyalet teftişleri ve 1864 vilayet nizamnamesi. Çăgdaş Yerel Yönetimler, 13, 93-123.

Ueno, M. (2013), "For the fatherland and the state": Armenians Negotiate the Tanzimat reforms, International journal of middle east studies, vol. 45, 1ssue: 1, February, pp. 93-109, (doi:10.1017/S0020743812001274)

Üçok,C. Mumcu, A. , Bozkurt, G. (2007), Türk hukuk tarihi. Ankara: Turhankitabevi.

Veldet, H. (1999), Kanunlaştırma Hareketi ve Tanzimat. Tanzimat I (ss. 139-209). İstanbul: Milli Eğitim Bakanlığg Yayınları.

Yılmazçelik, İ. (2019). Diyarbakır Eyaleti'nin Tanzimat'a Dahil Edilmesiyle Şehir ve Eyalet Yönetiminde Ortaya Çıkan Meseleler. Tanzimat'tan günümüze Diyarbakır (ss.21-62). Cilt 1 Elazığ: Manas Yayıncılık. 